\title{
MAKNA MEDIASI \\ DALAM UNDANG-UNDANG NOMOR 28 TAHUN 2014 TENTANG HAK CIPTA
}

\author{
Sudjana \\ Fakultas Hukum, Universitas Padjadjaran, Bandung \\ email: sdjana67@gmail.com
}

disampaikan 26/01/2020 - di-review 8/6/2020 - diterima 23/5/2021

DOI: $10.25123 /$ vej.v7i1.3716

\begin{abstract}
Art. 95(4) Law No. 28 of 2014 re. Copyright determines that mediation should be the preferred choice to settle copyright disputes, including those that relates to piracy and plagiarism. The issue to be discussed here is what would the legal consequence be in case this alternative dispute settlement is not utilized by disputants. This problem will be discussed using a juridical normative approach. Here, mediation is understood in the context of Law No. 30 of 1999 re. Arbitration and Alternative Dispute Settlement and Supreme Court Regulation No. 1 of 2016 re. Mediation Procedure in Court Proceedings. The main finding of this legal research is that mediation, by law, should be offered in court or may be used out of court at any time by disputants, in civil dispute (claim for compensation) as well in criminal cases. Non utilisation does not have as consequence the cessation of existing court proceedings.
\end{abstract}

Keywords:

alternative dispute settlements, mediation, copyright infringement

\begin{abstract}
Abstrak
Mediasi dalam Pasal 95(4) Undang-Undang No. 28 tahun 2014 tentang Hak Cipta ditetapkan sebagai pilihan metoda penyelesaian sengketa, termasuk yang berkaitan dengan pembajakan hak cipta. Pertanyaan utama di sini adalah apa konsekuensi hukum bila metoda penyelesaian sengketa ini tidak (dapat) digunakan. Untuk menelaah persoalan ini digunakan pendekatan yuridis normatif. Di sini mediasi harus dipahami dalam konteks Undang-Undang No. 30 tahun 1999 tentang Arbitrase dan Alternatif Penyelesaian Sengketa dan Peraturan Mahkamah Agung No. 1 tahun 2016 tentang Prosedur Mediasi di Pengadilan. Ditemukan bahwa alternatif penyelesaian sengketa melalui mediasi dibuka baik di dalam maupun di luar pengadilan, baik dalam sengketa keperdataan (tuntutan ganti rugi) maupun kasus pidana (pembajakan). Selanjutnya, tidak digunakannya mediasi tidak akan berakibat terhentinya proses pemeriksaan perkara tindak pidana.
\end{abstract}

Kata kunci:

alternatif penyelesaian sengketa, mediasi, pelanggaran hak cipta

\section{Pendahuluan}

Laporan IIPA (International Intellectual Property Alliance) menyebutkan bahwa sejumlah negara yang cukup parah melakukan pelanggaran hak cipta, 
antara lain Cina, Taiwan, India, Korea, Malaysia, dan Indonesia. ${ }^{1}$ Bentuk-bentuk pelangaran hak cipta yaitu Infringment (pengunaan secara tidak sah lewat copy atau pembajakan); Non Literal Coppping yaitu suatu ciptaan dengan cara menyusun kembali suatu ciptaan baru berdasarkan bahan-bahan yang berasal dari suatu ciptaan lain; dan Plagiat (Peniruan). ${ }^{2}$ Sepanjang tahun 2019, Kementerian Hukum dan HAM mencatat pelanggaran hak cipta sebanyak 7 kasus ${ }^{3}$, Mahkamah Agung RI mencatat terdapat 43 putusan untuk kasus Hak Cipta sebanyak 57 putusan. Hal ini menjadi bukti bahwa permasalahan Kekayaan Intelektual (KI) di Indonesia sebagai negara berkembang harus menjadi perhatian baik para pelaku usaha maupun pemerintah untuk mengurangi jumlah sengketa. ${ }^{4}$

Penyelesaian sengketa terhadap pelanggaran hak cipta dapat dilakukan secara konvensional yang dilakukan melalui pengadilan (jalur litigasi), tetapi perkembangan berikutnya timbul penyelesaian sengketa diluar pengadilan karena ketidakpuasan ${ }^{5}$ terhadap upaya penyelesaian sengketa melalui pengadilan, karena itu pada saat ini sudah mendesak dilakukannya pengembangan PnLg (penyelesaian sengketa non litigasi) dalam rangka mendayagunakan alternatif penyelesaian sengketa. ${ }^{6}$ Penyelesaian sengketa diluar pengadilan (non litigasi) yang dapat dilakukan melalui Arbitrase dan Alternatif Penyelesaian sengketa (APS) yaitu konsultasi, negosiasi, mediasi, konsiliasi, atau penilaian ahli sebagaimana diatur dalam Undang-undang Nomor 30 Tahun 1999 (selanjutnya disebut UU No 30 Tahun 1999). Namun, UU No 30 Tahun 1999 hanya mengatur mediasi "secara sumir" bahkan "pengertian mediasi" dalam Undang-Undang (UU)

Debora C. Surono, Penegakan Hukum Terhadap Pembajakan Karya Seni Musik Menurut Undang-Undang Nomor 28 Tahun 2014 Tentang Hak Cipta, Lex Privatum Vol. VI/No. 2/April/2018, hlm 121.

2 Ferol Mailangkay, Kajian Hukum Tentang Hak Moral Pencipta dan Pengguna Menurut UndangUndang Nomor 28 Tahun 2014 Tentang Hak Cipta, Lex Privatum Vol. V/No. 4/Jun/2017, hlm 141.

3 https://www.cnnindonesia.com/teknologi/20191231141341-185-461331/pelanggaranmerek-paling-banyak-diadukan-ke-kemenkumham. Diakses 10 Juni 2020.

4 www.putusan.mahkamahagung.go.id. Diakses 13 Juni 2020.

5 Sudjana, Efektivitas dan Efisiensi Penyelesaian Sengketa Kekayaan Intelektual Melalui Arbitrase dan Mediasi Berdasarkan Undang-Undang Nomor 30 Tahun 1999, Ajudikasi : Jurnal Ilmu Hukum, Vol. 2 No. 1, Juni 2018, hlm 82.

6 Ivan Renaldi, Optimalisasi Alternatif Penyelesaian Sengketa Hak Kekayaan Intelektual Bidang Desain Industri (Studi Industri Mebel dan Kerajinan Kabupaten Jepara), Privat Law , Vol: 6 NO: 1 2018, hlm 156. 
tersebut tidak ada, padahal menurut kelaziman, sebuah UU dalam Ketentuan Umum menjelaskan definisi atau pengertian. UU tersebut karena lebih banyak mengatur ketentuan tentang arbitrase karena itu UU No 30 Tahun 1999 tidak layak disebut sebagai "UU tentang Arbitrase dan Alternatif Penyelesaian Sengketa", lebih tepat lebih disebut " UU tentang Arbitrase."

Penyelesaian sengketa bertujuan untuk menyelesaikan ketidaksepakatan para pihak tentang sesuatu hal karena itu diantara kedua belah pihak melakukan negosiasi. Namun apabila "ego" kedua belah tinggi sehingga bersikukuh untuk menang dan pihak lain harus kalah (win-lose) maka penyelesaian melalui negosiasi tidak akan tercapai sehingga memerlukan pihak ketiga atau mediasi untuk menengahinya agar perkara tersebut dilakukan secara sederhana cepat dan biaya ringan, ${ }^{7}$ serta menghindari terjadinya penumpukan perkara.

Sengketa yang dapat diselesaikan melalui UU No. 30 Tahun 1999 adalah sengketa di bidang perdagangan atau bisnis, sehingga sengketa-sengketa yang timbul bukan berkaitan dengan bisnis dan tidak dapat diadakan perdamaian bukan merupakan obyek penyelesaian UU tersebut. ${ }^{8}$ Kemudian lahir Peraturan Mahkamah Agung (PERMA) No. 2 Tahun 2003 tentang Prosedur Mediasi di Pengadilan. PERMA ini bertujuan menyempurnakan Surat Edaran Mahkamah Agung (SEMA) No 1 Tahun 2002 tentang Pemberdayaan Pengadilan Tingkat Pertama dalam Menerapkan Lembaga Damai sebagaimana diatur dalam Pasal 130 Herziene Inlandsch Reglemen (HIR) "dan Pasal 154 Rechtsreglement voor de Buitengewesten (RBg). Pasal 130 HIR dan 154 RBg mengatur tentang lembaga perdamaian dan mewajibkan hakim untuk terlebih dahulu mendamaikan para pihak yang berperkara sebelum perkaranya diperiksa. ${ }^{9}$ PERMA No. 2 Tahun 2003 kemudian diubah pada tanggal 31 Juli 2008 oleh PERMA No. 1 Tahun 2008. PERMA ini terdiri atas VIII Bab dan 27 Pasal, tidak merujuk dan tidak pula mengacu kepada UU No. 30 Tahun 1999 karena tidak tercantum dalam

Pasal 2 ayat (4) UU No. 49 Tahun 2009 tentang Kekuasaan Kehakiman.

Supra No. 3.

9 http://www.pta-jambi.go.id/11-artikel/3870-implementasi-peraturan-mahkamah-agung-rinomor-1-tahun-2016-ten- tang- prosedur-mediasi-di-pengadilan. Diakses 7 Januari 2020. 
Konsiderans “ Mengingat.....dst" dari UU tersebut.10 Selanjutnya dengan pertimbangan bahwa PERMA No 1 Tahun 2008 belum optimal memenuhi kebutuhan pelaksanaan Mediasi yang lebih berdayaguna dan mampu meningkatkan keberhasilan Mediasi di Pengadilan, maka direvisi lagi melalui PERMA No. 1 Tahun 2016 Tentang proses mediasi di Pengadilan berkaitan dengan revisi dengan waktu pelaksanaan mediasi, itikad baik dalam melaksanakan mediasi, dan akibat hukum penggugat yang tidak beriktikad baik. ${ }^{11}$

Landasan hukum penyelesaian damai adalah Pasal 24 Undang-Undang Dasar Negara Republik Indonesia Tahun 1945 yang mengatakan "Kekuasaan kehakiman merupakan kekuasaan yang merdeka untuk menyelenggarakan peradilan guna menegakkan hukum dan keadilan." Selanjutnya, Pasal 10 ayat (2) UU Nomor 48 Tahun 2009 Tentang Kekuasaan Kehakiman, mengatakan bahwa “Ketentuan sebagaimana dimaksud pada Pasal 10 Ayat (1) UU No. 48 Tahun 2009 tidak menutup usaha penyelesaian perkara perdata secara perdamaian". Mediasi di luar pengadilan dalam UU No. 48 Tahun 2009 diatur pada Bab XII dari Pasal 58 sampai dengan Pasal 61. Empat pasal ini merujuk UU No. 30 Tahun 1999. Sedangkan mediasi di dalam pengadilan menurut UU tersebut diatur lebih lanjut dalam ketentuan terbaru yaitu PERMA No. 1 Tahun 2016.

Berkaitan dengan tindak pidana, ketentuan tentang mediasi dalam Pasal 95 (4) UU No. 28 Tahun 2014 tentang Hak Cipta mengatakan” “Selain pelanggaran Hak Cipta dan/atau Hak Terkait dalam bentuk Pembajakan, sepanjang para pihak yang bersengketa diketahui keberadaannya dan/atau berada di wilayah Negara Kesatuan Republik Indonesia harus menempuh terlebih dahulu penyelesaian sengketa melalui mediasi sebelum melakukan tuntutan pidana”. Namun, tidak ada kejelasan lebih lanjut di dalam penjelasan pasal tersebut "apakah makna mediasi tersebut merupakan cara penyelesaian di luar pengadilan sesuai dengan UU No 30 Tahun 1999 atau di dalam pengadilan sebagaimana diatur dalam PERMA No 1

10 Idris Talib, "Bentuk Putusan Penyelesaian Sengketa Berdasarkan Mediasi”, tersedia dalam file://C:/Users/user/AppData/Local/Temp/1295- 2482-1-SM.pdf. Diakses 9 Desember 2019.

11 Doni Dermawan, Implementasi Peraturan Mahkamah Agung RI Nomor 1 Tahun 2016 Tentang Prosedur Mediasi di Pengadilan. http://www.pta-jambi.go.id/11-artikel/3870-implementasiperaturan-mahkamah-agung-ri-nomor-1-tahun-2016-tentang-prosedur-mediasi-dipengadilan. Diakses 5 Desember 2019. 
Tahun 2016". Ketentuan tersebut juga tidak menjelaskan lebih lanjut, akibat hukumnya apabila mediasi untuk tindak pidana selain pembajakan tidak dilakukan, apakah perkara pidananya berhenti atau tidak diproses (tidak diterima) atau tetap berlanjut/diproses sesuai dengan ketentuan hukum yang berlaku.

Berdasarkan hal itu, kajian ini membahas permasalahan sebagai berikut: Bagaimana makna mediasi dalam Pasal 95 ayat (4) Undang-undang No. 28 Tahun 2014 tersebut dikaitkan dengan Jenis penyelesaian sengketa? Bagaimana akibat hukum tidak dilakukan Mediasi dalam Pasal 95 (4) Undang-undang No. 28 Tahun $2014 ?$

\section{Pembahasan}

Makna Mediasi dalam Pasal 95 ayat (4) Undang-Undang Nomor 28 Tahun 2014 dikaitkan dengan Jenis Penyelesaian Sengketa

Istilah "Sengketa" atau "Disputes" (bahasa Inggris), seringkali disebut dengan "konflik" atau conflict (bahasa Inggris). Henry Campbell Black menjelaskan arti "dispute", sebagai: "A conflict of controversy; a conflict of claims or rights; an assentation of a right, claim, or demand on one side, met by contrary claims or allegations on the other. The subject of litigation; the matter for which a suit is brought and upon which issue is joined, and in relation to which jurors are called and witnesses examined."12

Penyelesaian sengketa secara litigasi dilakukan melalui pengadilan niaga yang berwenang memeriksa, mengadili dan memberi putusan terhadap perkara kepailitan dan Penundaan Kewajiban dan Pembayaran Utang (PKPU), sengketa-sengketa komersial lainnya seperti sengketa di bidang KI dan sengketa dalam proses likuidasi bank yang dilakukan Lembaga Penjamin Simpanan (LPS). Namun, penyelesaian sengketa melalui pengadilan menimbulkan ketidakpuasan (dissatisfaction), $\quad$ konfrontatif dan zwaarwichtig (njelimet-bertele-tele), ${ }^{13}$

12 Henry Campbell Black, Black's Law Dictionary, West Publishing Co., St. Paul, 1989, page 424.

13 Sholih Mu'adi: Penyelesaian Sengketa Hak Atas Tanah Perkebunan Dengan cara Litigasi Dan Nonlitigasi, Jakarta, Prestasi Pustakarya, 2010, hlm 66. lihat juga Yuniar Kurniawaty, Efektivitas Alternatif Penyelesaian Sengketa Dalam Sengketa Kekayaan Intelektual (Alternative 
meskipun waktunya dibatasi tetapi masih dapat kasasi. Karena itu muncul penyelesaian sengketa alternatif (Alternative Dispute Resolution= ADR) atau penyelesaian sengketa di luar pengadilan.

Penyelesaian sengketa di luar pengadilan dilakukan melalui negosiasi, mediasi, konsiliasi, penilaian ahli dan arbitrase. Negosiasi merupakan penyelesaian sengketa sepenuhnya dikontrol oleh kedua belah pihak, sifatnya informal, yang dibahas adalah berbagai aspek, tidak hanya persoalan hukum saja. ${ }^{14}$ Konsiliasi adalah Penyelesaian sengketa dengan intervensi pihak ketiga (konsiliator) lebih bersifat aktif, dengan mengambil inisiatif menyusun dan merumuskan langkah-langkah penyelesaian, yang selanjutnya ditawarkan kepada para merumuskan suatu kesepakatan. Konsiliator tidak berwenang membuat putusan, tetapi hanya berwenang membuat rekomendasi, yang pelaksanaanya bergantung pada iktikad baik para pihak yang bersengketa. Penilaian ahli Pendapat untuk suatu hal yang bersifat teknis sesuai dengan bidang keahliannya. ${ }^{15}$ Arbitrase adalah cara penyelesaian suatu sengketa perdata di luar peradilan umum yang didasarkan pada perjanjian arbitrase yang dibuat secara tertulis oleh para pihak yang bersengketa. ${ }^{16}$

Istilah "Mediasi" dalam bahasa Inggris dinamakan "Mediation" yang diartikan oleh Munir Fuady sebagai "suatu proses penyelesaian sengketa berupa negosiasi untuk memecahkan masalah melalui pihak luar (ketiga) yang netral (mediator) dan tidak memihak, untuk membantu menemukan solusi dalam menyelesaikan sengketa tersebut secara memuaskan kedua belah pihak. ${ }^{17}$ Prinsip dasar (basic principle) menurut David Spencer dan Michael Brogan merujuk pada

Dispute Resolution On Intellectual Property Dispute), Jurnal Legislasi, Vol. 14 No. 02 - Juni 2017, hlm 163 - 170 .

14 Dewi Tuti Muryati, and B. Rini Heryanti. "Pengaturan dan Mekanisme Penyelesaian Sengketa Nonlitigasi di Bidang Perdagangan.” Jurnal Dinamika Sosbud 3, No. 1 (2011), hlm 56. http://ilib.usm.ac.id/sipp/doc/jurnas/gdl-usm--dewitutimu-87-1-pengatur-e.pdf. Diakses 5 Januari 2020.

15 Ros Angesti Anas Kapindha, Salvatia Dwi M, and Winda Rizky Febrina, "Efektivitas dan Efisiensi Alternative Dispute Resolution (ADR) Sebagai Salah Satu Penyelesaian Sengketa Bisnis Di Indonesia", Privat Law 12 , No. 4 (2014), hlm 8.

16 Pasal 1 angka (1) UU No 30 Tahun 1999 tentang Arbitrase dan Penyelesaian Sengketa Alternatif.

17 Munir Fuady, Pengantar Hukum Bisnis, Menata Bisnis Modern di Era Global, 2003, PT Citra Aditya Bakti, Bandung, 2002, hlm 314. 
pandangan Ruth Carlton tentang lima prinsip dasar filsafat mediasi yaitu prinsip kerahasiaan (confidentiality), prinsip sukarela (volunteer) prinsip pemberdayaan (empowerment), prinsip netralitas (neutrality), dan prinsip solusi yang unik (a unique solution). ${ }^{18}$

Mediasi melibatkan pihak ketiga yang netral, tetapi tidak memiliki kewenangan mengambil keputusan untuk membantu pihak-pihak yang bersengketa mencapai penyelesaian (solusi) yang diterima oleh kedua belah pihak. ${ }^{19}$ Khotibul Umam ${ }^{20}$ berpendapat bahwa mediasi itu adalah proses negosiasi pemecahan masalah, para pihak yang tidak memihak (mediator) bekerja sama dengan pihak yang bersengketa untuk mencari kesepakatan bersama tetapi tidak berwenang untuk memutus sengketa, hanya membantu para pihak untuk menyelesaikan persoalan-persoalan yang dikuasakan kepadanya. Pendapat Khotibul Umam sejalan dengan Christopher W. Moore ${ }^{21}$ memberikan batasan tentang pengertian mediasi adalah intervensi terhadap suatu sengketa/negosiasi oleh pihak ketiga yang dapat diterima, tidak berpihak dan netral yang tidak mempunyai kewenangan untuk mengambil keputusan dalam membantu para pihak yang berselisih dalam upaya mencapai kesepakatan secara sukarela dalam penyelesaian permasalahan yang disengketakan.

Makna mediasi dikaitkan dengan penyelesaian di dalam pengadilan dikemukakan oleh Takdir Rahmadi22, Hakim Agung/Ketua Kelompok Kerja Mediasi, berpendapat bahwa mediasi itu adalah penyelesaian sengketa melalui cara perundingan/musyawarah mufakat para pihak dengan bantuan pihak netral (mediator) yang tidak memiliki kewenangan memutus dengan tujuan menghasilkan kesepakatan damai untuk mengakhiri sengketa. Hal ini sejalan

\footnotetext{
18 Marthen B. Salinding, "Dasar Filosofi Mediasi Sebagai Pilihan Penyelesaian Sengketa Lingkungan Hidup", garuda. risetdikti, (2017), hlm 47.

19 Dewi Tuti Muryati dan B. Rini Heryanti, supra No. 14. Lihat juga Taufikkurrahman, Alternative Dispute Resolution (ADR). Dalam Penyelesaian Sengketa Konsumen, Iqtishadia, Jurnal Ekonomi Perbankan Syariah, Vol. 2 No. 1 (2015), hlm 32.

20 Khotibul Umam, Penyelesaian Sengketa di luar Pengadilan, Pustaka Yustisia,Yoyakarta, 2010, hlm 10.

21 Joni Emirzon, Alternatif Penyelesaian Sengketa di Luar Pengadilan, Gramedia Pustaka Utama, Jakarta, 2001, hlm 68.

22 Id.
} 
dengan ketentuan Pasal 1 angka (1) PERMA No 1 Tahun 2016 yang berbunyi "Mediasi adalah cara penyelesaian sengketa melalui proses perundingan untuk memperoleh kesepakatan Para Pihak dengan dibantu oleh Mediator".

Adapun jenis sengketa Jenis sengketa ${ }^{23}$ yang dapat di mediasi meliputi (1). konflik Interest, apabila dua orang yang memiliki keinginan yang sama terhadap satu obyek yang dianggap bernilai dan (2). klaim kebenaran, yang menganggap pihak lain bersalah sehingga argumen klaim didasarkan pada terminologi kebenaran, bukan kepentingan, norma-norma dan hukum. Dalam kaitan dengan Pasal 95 ayat (4) UU No. 28 Tahun 2014, jenis sengketanya lebih cenderung pada klaim kebenaran karena hendak menentukan kualifikasi mediasi sebagai penyelesaian sengketa di dalam atau di luar pengadilan serta akibat hukum berkaitan dengan ketentuan tersebut.

Penyelesaian sengketa KI antara Hak Cipta tercantum dalam ketentuan Pasal 95 UU No 28 Tahun 2014 tentang Hak Cipta yang berbunyi:

(1). Penyelesaian sengketa Hak Cipta dapat dilakukan melalui alternatif penyelesaian sengketa, arbitrase, atau pengadilan.

(2). Pengadilan yang berwenang sebagaimana dimaksud ayat (1) adalah Pengadilan Niaga.

(3). Pengadilan lainnya selain Pengadilan Niaga sebagaimana dimaksud ayat (2) tidak berwenang menangani penyelesaian sengketa Hak Cipta.

(4). Selain pelanggaran Hak Cipta dan/atau Hak Terkait dalam bentuk Pembajakan, sepanjang para pihak yang bersengketa diketahui keberadaannya dan/atau berada di wilayah Negara Kesatuan Republik Indonesia harus menempuh terlebih dahulu penyelesaian sengketa melalui mediasi sebelum melakukan tuntutan pidana.

Penjelasan Pasal 95 ayat (1) mengatakan "Bentuk sengketa terkait dengan Hak Cipta antara lain, sengketa berupa perbuatan melawan hukum, perjanjian Lisensi, sengketa mengenai tarif dalam penarikan imbalan atau Royalti." Sedangkan makna Pasal 95 ayat (2) dan (3) berkaitan dengan kewenangan absolut dari pengadilan niaga untuk mengadili sengketa berkaitan dengan Hak Cipta ${ }^{24}$ diluar

23 https://www.kajianpustaka.com/2018/10/pengertian-jenis-penyebab-dan-penyelesaiansengketa. html. Diakses 27 Desember 2020.

24 Hak Cipta adalah hak eksklusif pencipta yang timbul secara otomatis berdasarkan prinsip deklaratif setelah suatu ciptaan diwujudkan dalam bentuk nyata tanpa mengurangi 
pengadilan negeri (meskipun kedudukannya berada di Pengadilan negeri) agar perkara tersebut lebih cepat selesai.

Pembajakan merupakan penggandaan atas hak cipta secara ilegal atau tanpa izin ${ }^{25}$. Pembajakan adalah Penggandaan Ciptaan $^{26}$ ( proses, perbuatan, atau cara menggandakan satu salinan Ciptaan dan/atau fonogram ${ }^{27}$ atau lebih dengan cara dan dalam bentuk apapun, secara permanen atau sementara) dan/atau produk Hak Terkait secara tidak sah dan pendistribusian barang hasil penggandaan dimaksud secara luas untuk memperoleh keuntungan ekonomi. ${ }^{28}$ Hak Terkait adalah hak yang berkaitan dengan Hak Cipta yang merupakan hak eksklusif (Hak ekonomi dan Hak moral) bagi pelaku pertunjukan, produser fonogram, atau lembaga Penyiaran. Pembajakan (piracy) berbeda dengan pengambilan karya cipta oleh pihak lain secara tidak sah dan menjadikannya seolah-olah karya sendiri (peniruan atau plagiarism). ${ }^{29}$ Dengan demikian, pada plagiarism terjadi pelanggaran hak moral dan dapat juga hak ekonomi (apabila dilakukan komersialisasi), sedangkan piracy, tidak terjadi pelanggaran hak moral karena pencipta atau pemegang hak cipta tidak dihilangkan, tetapi terjadi pelanggaran hak ekonomi. Namun, kedua hak tersebut ( pemegang hak ekonomi

pembatasan sesuai dengan ketentuan peraturan perundang-undangan. Lihat Pasal 1 angka (15) UU No. 28 Tahun 2014.

25 Aditya Pandu Wicaksono dan Dekar Urumsah, Perilaku Cerita Dari Mahasiswa Yogyakarta, Jurnal Aplikasi Bisnis, Volume 17 Nomor 1 Bulan Juli 2017. Lihat juga Riandhani Septian Chandrika, Raymond Edo Dewanta Magister Kenotariatan, Fakultas Hukum, Universitas Airlangga Pembajakan Produk Digital : Kajian Kritis Konsep Pembajakan di Bidang Hak Cipta Dalam Perspektif Hukum Positif dan Hukum Islam, RechtIdee, Vol. 14, No. 1, Juni 2019, hlm 127-149.

26 Penggandaan adalah proses, perbuatan, atau cara menggandakan satu salinan Ciptaan dan/atau fonogram atau lebih dengan cara dan dalam bentuk apapun, secara permanen atau sementara. Lihat Pasal 1 angka (12) supra No.24. Sedangkan Ciptaan adalah setiap hasil karya cipta di bidang ilmu pengetahuan, seni, dan sastra yang dihasilkan atas inspirasi, kemampuan, pikiran, imajinasi, kecekatan, keterampilan, atau keahlian yang diekspresikan dalam bentuk nyata. Id Pasal 1 angka (3).

27 Fonogram adalah Fiksasi suara pertunjukan atau suara lainnya, atau representasi suara, yang tidak termasuk bentuk Fiksasi yang tergabung dalam sinematografi atau Ciptaan audiovisual lainnya. Lihat Pasal 1 angka (14). Fiksasi adalah perekaman suara yang dapat didengar, perekaman gambar atau keduanya, yang dapat dilihat, didengar, digandakan, atau dikomunikasikan melalui perangkat apapun. Id Pasal 1 angka (13).

28 Id. Pasal 1 angka (23).

29 Nahrowi, Plagiat dan pembajakan Karya Cipta dalam Hak Kekayaan Intelektual, Salam : Jurnal Filsafat dan Budaya hukum, 227-238, http://repository. uinjkt.ac.id/dspace/bitstream/ 123456789/ 31355/1/ Nahrowi.pdf. Diakses 15 Januari 2020. 
dan moral) secara filosofis perlu dilindungi sebagaimana aliran hukum alam yang dikemukakan oleh John Locke (1632-1704) dan Jean Jacques Rousseau(17121778). Menurut Locke, setiap orang secara alamiah memiliki hak atas dirinya sendiri dan- oleh karena itu - hasil pekerjaannya (labour) karena telah melakukan pengorbanan dalam bentuk menemukan, mengolah, dan menambahkan "kepribadian" ke dalam sesuatu, sebagaimana diungkapkan sebagai berikut: 30 "...yet every man has a "property" in his own 'person'. This nobody has any right to but himself. The 'labour' of his body and the 'work' of his hands, we may say, are properly his. Whatsoever, then, he removes out of the state that Nature hath provided and left it in, he hath mixed his labour with it, and joined to it something that is his own, and thereby makes it his property."

Locke tidak melihat pengorbanan seseorang melalui tenaganya secara harfiah, sebagai justifikasi perlindungan kekayaan intelektual tetapi sesuatu yang dihasilkan melalui aktivitas seseorang memberikan nilai sosial yang tinggi bagi masyarakat. Dengan demikian, nilai sosial itulah yang menjadi dasar pemberian penghargaan. Locke mengungkapkan hal tersebut sebagai berikut: “...labor often creates social value, and it is this production of social value that 'deserves' reward, not the labor that produced it". 31

"Kepribadian" sebagaimana yang dijelaskan oleh Locke tersebut di atas, kemudian dikembangkan menjadi sebuah teori yang disebut Personality Theory, yang didasarkan kepada pandangan Georg Wilhelm Friedrich Hegel (1770-1831). Menurut Hegel, "the individual's will is the core of the individual's existence...constantly seeking actuality...and effectiveness in the world." Teori ini dianggap sebagai refleksi paham kebebasan yang menurut Hegel harus diwujudkan dalam bentuk suatu karya cipta agar menjadi terlihat jelas. ${ }^{32}$

30 Locke, J. The Second Treatise of Government (Barnes \& Noble Publishing Inc, USA, 2004), hlm 17-19. Lihat juga Basuki Antariksa, Landasan Filosofis dan Sejarah Perkembangan Perlindungan Hak Kekayaan Intelektual: Relevansinya Bagi Kepentingan Pembangunan Di Indonesia, https://www.kemenpar. go.idasset_admin/assets/uploads/media/ old_all/Art_19Landasan\%20Filosofis\%20HKI.pdf. Diakses 7 Desember 2019.

31 Hughes, J. The Philosophy of Intellectual Property. Georgetown Law Journal, 77(287), 1998, hlm $12,14-17,42$.

32 Basuki Antariksa , "Landasan Filosofis dan Sejarah Perkembangan Perlindungan Hak Kekayaan Intelektual: Relevansinya Bagi Kepentingan Pembangunan Di Indonesia". 
Dalam perkembangannya kemudian, aliran Hukum Alam ini kehilangan pengaruhnya karena munculnya paham baru yang dinamakan Utilitarian Theory. Pengertian paham tersebut dapat diketahui dari pandangan salah satu tokoh aliran Utilitarian, Jeremy Bentham (1748-1832). ${ }^{33}$ Pendukung aliran Utilitarian berpendapat bahwa: "...IPR was created by society for the purpose of serving the economic interests of its members at large". Hal ini berarti, KI bukan hak alamiah seseorang, melainkan diberikan oleh Pemerintah untuk menjamin kepentingan ekonomi masyarakat yang lebih luas. Menurut aliran ini pula, perlindungan KI bukanlah tujuan utama, melainkan "...only tools to another greater end: progress". Karena itu suatu karya pada suatu saat akan menjadi public domain untuk mendorong setiap orang menciptakan karya baru. ${ }^{34}$

Berdasarkan kedua teori tersebut, pencipta atau pemegang KI (hak cipta) mendapat perlindungan hukum berkaitan dengan kreasi yang dihasilkannya. Hal ini berarti apabila KI yang dilanggar, maka terjadi sengketa dalam hal pencipta atau pemegang hak cipta melakukan tindakan hukum baik melalui jalur pengadilan maupun di luar pengadilan (antara lain mediasi).

Implementasi teori tersebut dalam penyelesaian sengketa secara mediasi melalui pengadilan, diatur dalam Pasal 4 ayat (2) huruf a angka 1 PERMA No.1 Tahun 2016 yang berbunyi:

(1). Semua sengketa perdata yang diajukan ke Pengadilan termasuk perkara perlawanan (verzet) atas putusan verstek dan perlawanan pihak berperkara (partij verzet) maupun pihak ketiga (derden verzet) terhadap pelaksanaan putusan yang telah berkekuatan hukum tetap, wajib terlebih dahulu diupayakan penyelesaian melalui Mediasi, kecuali ditentukan lain berdasarkan Peraturan Mahkamah Agung ini."

(2). Sengketa yang dikecualikan dari kewajiban penyelesaian melalui Mediasi sebagaimana dimaksud pada ayat (1) meliputi:

a. sengketa yang pemeriksaannya di persidangan ditentukan tenggang waktu penyelesaiannya meliputi antara lain:

1. sengketa yang diselesaikan melalui prosedur Pengadilan Niaga;

https://www.kemenpar. go.idasset admin/ assets/ uploads/ media/ old all/Art 19Landasan\%20Filosofis\%20HKI.pdf. Diakses 7 Desember 2019.

33 Jeremy Bentham, An Introduction to the Principles of Morals and Legislation. http://books.google. co.id/. Diakses 24 Desember 2019.

34 Basuki Antariksa, supra No. 32. 
Berdasarkan Pasal 4 ayat (2) huruf a angka 1 PERMA No.1 Tahun 2016, mediasi untuk sengketa yang diselesaikan di Pengadilan Niaga (dalam hal ini adalah sengketa Hak cipta) tidak mewajibkan dilakukan terlebih dahulu mediasi. Sedangkan ketentuan Pasal 95 ayat (4) UU No 28 Tahun 2014 yang mewajibkan mediasi kecuali tindak pidana pembajakan (piracy). Padahal dalam perspektif hukum Kekayaan Intelektual dapat terjadi tindak pidana selain pembajakan, misalnya plagiarism (peniruan) yang penyelesaiannya bukan kewenangan Pengadilan Niaga tetapi kompetensi absolut Pengadilan Negeri karena berkaitan dengan "tindak pidana", tetapi pihak yang merasa dirugikan dapat menempuh upaya melalui gugatan hukum perdata berdasarkan perbuatan melawan hukum. Gugatan perbuatan melawan hukum berkaitan dengan KI diajukan kepada Pengadilan Niaga yang berarti tidak wajib melakukan mediasi berdasarkan Pasal 4 ayat (2) huruf a angka 1 PERMA No.1 Tahun 2016, sedangkan berdasarkan Pasal 95 ayat (4) UU No 28 Tahun 2014, untuk plagiarisme wajib dilakukan mediasi karena ketentuan tersebut mengatakan "kecuali pembajakan", artinya untuk perbuatan melawan hukum wajib melakukan mediasi. Hal ini berarti ada ketidaksinkronan antara makna mediasi dalam Pasal 4 ayat (2) huruf a angka 1 PERMA No.1 Tahun 2016 dengan mediasi yang tercantum Pasal 95 ayat (4) Undang-Undang Nomor 28 Tahun 2014 tentang Hak Cipta. Dengan demikian, makna mediasi yang dimaksud dalam ketentuan Pasal 95 ayat (4) UU No 28 Tahun 2014 jo Pasal 95 ayat (1) UU No 28 Tahun 2014 harus ditafsirkan secara sistematis (penafsiran sistematis) dan prinsip hukum yang lebih tinggi (undangundang Hak cipta) mengenyampingkan hukum yang lebih rendah (PERMA No.1 Tahun 2016) atau "lex superior derogat lex inferiori" bukan mediasi di pengadilan melainkan mediasi di luar pengadilan yang merujuk pada UU No 30 Tahun 1999 atau Penyelesaian sengketa melalui Badan Arbitrase dan Mediasi (BAM) KI.

Penyelesaian sengketa melalui mediasi memerlukan beberapa tahapan yang harus dilalui. Menurut Jacqueline M. \& Nolan- Haley ada beberapa tahapan yang harus dilakukan dalam mediasi, yaitu : (1) screening; (2) mediator describes 
process and role of mediator; (3) mediator assists parties in drafting agreement. ${ }^{35}$ Sedangkan menurut Pasal 6 ayat (1) UU No 30 Tahun 1999, sengketa atau beda pendapat perdata dapat diselesaikan oleh para pihak melalui alternatif penyelesaian sengketa yang didasarkan pada itikad baik dengan mengesampingkan penyelesaian secara litigasi di Pengadilan Negeri. Lebih lanjut, Pasal 6 ayat (2) UU No 30 Tahun 1999 menjelaskan: penyelesaian sengketa atau beda pendapat melalui alternatif penyelesaian sengketa diselesaikan dalam pertemuan langsung oleh para pihak dalam waktu paling lama 14 (empat belas) hari dan hasilnya dituangkan dalam suatu kesepakatan tertulis. Dalam hal sengketa atau beda pendapat tidak dapat diselesaikan, maka atas kesepakatan tertulis para pihak, sengketa atau beda pendapat diselesaikan melalui bantuan seorang atau lebih penasehat ahli maupun melalui seorang mediator. Apabila para pihak tersebut dalam waktu paling lama 14 (empat belas) hari dengan bantuan seorang atau lebih penasehat ahli maupun melalui seorang mediator tidak berhasil mencapai kata sepakat, atau mediator tidak berhasil mempertemukan kedua belah pihak, maka para pihak dapat menghubungi sebuah lembaga arbitrase atau lembaga alternatif penyelesaian sengketa untuk menunjuk seorang mediator. Setelah penunjukan mediator oleh Lembaga arbitrase atau lembaga alternatif penyelesaian sengketa, dalam waktu paling lama 7 (tujuh) hari usaha mediasi harus sudah dapat dimulai. Usaha penyelesaian sengketa atau beda pendapat melalui mediator dengan memegang teguh kerahasiaan, dalam waktu paling lama 30 (tiga puluh) hari harus tercapai kesepakatan dalam bentuk tertulis yang ditandatangani oleh semua pihak yang terkait. Kesepakatan penyelesaian sengketa atau beda pendapat secara tertulis adalah final dan mengikat para pihak untuk dilaksanakan dengan itikad baik serta wajib didaftarkan di Pengadilan Negeri dalam waktu paling lama 30 (tiga puluh) hari sejak penandatanganan. Kesepakatan penyelesaian sengketa atau beda pendapat wajib selesai dilaksanakan dalam waktu paling lama 30 (tiga puluh) hari sejak pendaftaran. Apabila usaha perdamaian sampai dengan ayat (6) tidak dapat dicapai, maka para

35 Supra No. 13. 
pihak berdasarkan kesepakatan secara tertulis dapat mengajukan penyelesaian melalui lembaga arbitrase atau arbitrase ad-hoc.

Penyelesaian sengketa KI melalui Arbitrase dan Mediasi dapat juga diajukan melalui Badan Arbitrase dan Mediasi KI (BAM KI) yang sudah terbentuk sejak tahun 2011 tetapi ternyata belum berjalan efektif padahal penyelesaian sengketa melalui BAM KI memiliki keuntungan antara lain perkara itu tertutup untuk umum, sehingga kasus tersebut tidak akan terekspos ke luar dan jangka waktu penyelesaian dibatasi selama 180 hari. Artinya, selama dalam kurun waktu itu, perkara yang ditangani oleh BAM KI sudah harus diputus oleh Majelis Arbiter. ${ }^{36}$

Penyelesaian sengketa melalui BAM KI menurut Zen Umar Purba, prosedurnya sederhana dan biaya relatif lebih murah serta putusan bersifat final dan mengikat para pihak yang bersengketa. ${ }^{37}$ Namun, mediasi dan arbitrase bukan tanpa keterbatasan. Arbitrase misalnya yang dinilai tidak mengenal konsep 'yurisprudensi' sehingga memungkinkan terjadinya perbedaan putusan dalam perkara yang hampir serupa pokok perkaranya. Selain itu, mediasi dan arbitrase sangat tergantung pada iktikad baik dan komitmen para pihak untuk melaksanakan isi putusan. Sebab, kalau tidak didasari iktikad baik dan komitmen kedua pihak, kesepakatan atau putusan itu akan mentah kembali. ${ }^{38}$

Berdasarkan uraian yang telah dijelaskan bahwa makna mediasi yang dimaksud dalam ketentuan Pasal 95 ayat (4) UU No 28 Tahun 2014 jo Pasal 95 ayat (1) UU No 28 Tahun 2014 adalah mediasi non litigasi yang merujuk pada UU No 30 Tahun 1999 atau Penyelesaian sengketa melalui Badan Arbitrase dan Mediasi (BAM) KI. Mediasi non litigasi adalah sarana untuk menyelesaikan sengketa melalui pola pikir bahwa hukum harus peka terhadap perubahan di masyarakat karena hukum bertujuan untuk mencapai kesejahteraan dan kebahagian sehingga mempunyai watak menolak "status quo" Pemikiran tersebut

\footnotetext{
36 http://www.patenindonesia.com/?p=682. Diakses 17 Desember 2019.

37 Zen Umar Purba, Peranan BAM HKI dalam Penyelesaian Permasalahan Lembaga Manajemen Kolektif, Seminar, 2013.

38 https://www.hukumonline.com/berita/baca/lt5118dd47bc07e/arbitrase-dan-mediasi-hkibelum-dilirik/. Diakses 20 Desember 2019.
} 
merupakan gagasan dari hukum progresif yang dikemukakan oleh Satjipto Rahardjo bahwa" Hukum progresif tidak menerima hukum sebagai institusi yang mutlak serta final, melainkan sangat ditentukan oleh kemampuannya untuk mengabdi kepada manusia. Dalam konteks pemikiran tersebut, hukum selalu berada dalam proses untuk terus menjadi, ${ }^{39}$ mencari berbagai terobosan untuk mendapatkan manfaat yang lebih besar. Oleh karena itu, Hukum progresif memandang bahwa mediasi adalah suatu cara yang sangat produktif, kreatif, dan inovatif untuk memanusiakan manusia menjadikan hukum sebagai sebuah institusi yang melayani dan membahagiakan manusia ${ }^{40}$ melalui penyelesaian sengketa yang efektif dikaitkan dengan tujuan hukum yang hendak dicapai, yaitu kepastian, keadilan dan kemanfaatan. Adapun mekanisme penyelesaian sengketa yang efektif tersebut menyangkut efektifitas keberlakuan dari hukum yang diterapkan; proses pengambilan keputusan yang cepat dan biaya yang wajar; netralitas dan profesionalisme dalam proses pengambilan keputusan; efektifitas pelaksanaan atau implementasi keputusan; dan kepatuhan para pihak terhadap keputusan yang dihasilkan. ${ }^{41}$

\section{Akibat hukum tidak dilakukan Mediasi dalam Pasal 95 (4) Undang-Undang Nomor 28 Tahun 2014}

Akibat hukum adalah suatu tindakan yang dilakukan untuk memperoleh suatu akibat yang dikehendaki oleh pelaku dan yang diatur oleh hukum. Tindakan ini dinamakan tindakan hukum, sehingga akibat hukum adalah akibat dari suatu tindakan hukum. ${ }^{42}$ Akibat hukum timbul karena adanya perbuatan dari subyek hukum baik bersifat pasif (tidak melakukan perbuatan) maupun aktif (melakukan perbuatan) sehingga berakibat batal demi hukum (null and void nietig) atau dapat dibatalkan (voidable/vernietigbaar). Perbedaannya adalah batal demi hukum,

39 Satjipto Rahardjo, Hukum Progresif Sebuah Sintesa Hukum Indonesia, Genta Publishing, Yogyakarta, 2009, hlm. 5-6.

40 Kamaruddin, Mediasi Dalam Pandangan Hukum Progresif Suatu Alternatif Penyelesaian Konflik Keluarga, Jurnal Al-'Adl, Vol. 11 No. 2, Juli 2018, hlm. 17.

41 Ida Bagus Rahmadi Suprananca, Kerangka Hukum dan Kebijakan Investasi Langsung di Indonesia, cet. 1, Ghalia Indonesia, Bogor, 2006, hlm. 8-9.

42 R. Soeroso, Pengantar Ilmu Hukum, Sinar Grafika, Jakarta, 2011, hlm. 295. 
tidak memerlukan tindakan apapun untuk membatalkan karena hukum dengan sendirinya menyatakan bahwa perbuatan tersebut tidak ada atau batal. Sedangkan dapat dibatalkan, selama tindakan membatalkan belum dilakukan, maka perbuatan tersebut oleh hukum dianggap ada karena itu agar perbuatan tersebut batal perlu ada tindakan untuk melakukan pembatalan.

Penyelesaian sengketa atau beda pendapat melalui alternatif penyelesaian sengketa berdasarkan UU No 30 Tahun 1999 diselesaikan dalam pertemuan langsung oleh para pihak dalam waktu paling lama 14 (empat belas) hari dan hasilnya dituangkan dalam suatu kesepakatan tertulis. Dalam hal sengketa atau beda pendapat tidak dapat diselesaikan, maka atas kesepakatan tertulis para pihak, sengketa atau beda pendapat diselesaikan melalui bantuan seorang atau lebih penasehat ahli maupun melalui seorang mediator. Apabila para pihak tersebut dalam waktu paling lama 14 (empat belas) hari dengan bantuan seorang atau lebih penasehat ahli maupun melalui seorang mediator tidak berhasil mencapai kata sepakat, atau mediator tidak berhasil mempertemukan kedua belah pihak, maka para pihak dapat menghubungi sebuah lembaga arbitrase atau lembaga alternatif penyelesaian sengketa untuk menunjuk seorang mediator. Setelah penunjukan mediator oleh lembaga arbitrase atau lembaga alternatif penyelesaian sengketa, dalam waktu paling lama 7 (tujuh) hari usaha mediasi harus sudah dapat dimulai. Usaha penyelesaian sengketa atau beda pendapat melalui mediator dengan memegang teguh kerahasiaan, dalam waktu paling lama 30 (tiga puluh) hari harus tercapai kesepakatan dalam bentuk tertulis yang ditandatangani oleh semua pihak yang terkait. Kesepakatan penyelesaian sengketa atau beda pendapat secara tertulis adalah final dan mengikat para pihak untuk dilaksanakan dengan itikad baik serta wajib didaftarkan di Pengadilan Negeri dalam waktu paling lama 30 (tiga puluh) hari sejak penandatanganan. Kesepakatan penyelesaian sengketa atau beda pendapat wajib selesai dilaksanakan dalam waktu paling lama 30 ( tiga puluh) hari sejak pendaftaran. Apabila usaha perdamaian tidak dapat dicapai, maka para pihak berdasarkan kesepakatan secara tertulis dapat mengajukan usaha penyelesaiannya melalui lembaga arbitrase atau arbitrase ad-hoc. 
Ketentuan Pasal 95 ayat (4) UU No 28 Tahun 2014 jo UU No 30 Tahun 1999 tidak menjelaskan akibat hukum apabila tidak dilakukannya mediasi, apakah perkara pidananya gugur atau tetap diteruskan melalui pengadilan?. Hal ini memicu terjadi kekosongan hukum atau "rechvaccum" yang berakibat pada ketidakpastian hukum berkaitan dengan mediasi untuk tindak pidana selain pembajakan, misalnya peniruan (plagiarism). Oleh karena itu, apabila kasus tersebut sampai ke pengadilan tetap harus diproses karena hakim dianggap mengetahui seluruh UU (ius curia novit), dan menurut Pasal 10 ayat (1) UndangUndang No.48 Tahun 2009 tentang Kekuasaan Kehakiman "pengadilan dilarang menolak untuk memeriksa, mengadili, dan memutus suatu perkara yang diajukan dengan dalih bahwa hukum tidak ada atau kurang jelas, melainkan wajib untuk memeriksa dan mengadilinya. Ketentuan tersebut tidak menutup usaha penyelesaian perkara perdata secara perdamaian sebagaimana diatur dalam Pasal 1851 s/d 1864 KUHPerdata. Hakim perlu melakukan penemuan hukum (penafsiran hukum) berdasarkan Penjelasan Pasal 5 ayat (1) Undang-undang Nomor 48 Tahun 2009 yaitu "Hakim wajib menggali, mengikuti, dan memahami nilai-nilai hukum dan rasa keadilan yang hidup dalam masyarakat," agar putusan hakim sesuai dengan hukum dan rasa keadilan masyarakat.

Penulis berpendapat bahwa keharusan dilakukan mediasi dalam sengketa KI kecuali pembajakan merupakan norma yang bersifat memaksa karena pada saat proses di gelar di persidangan di Pengadilan negeri, untuk perkara yang mewajibkan mediasi, hakim harus menanyakan terlebih dahulu bahwa mediasi telah dilakukan. Dengan demikian apabila mediasi tidak dilakukan, perkara pidananya tetap berlanjut bukan berhenti dengan alasan "karena kewajiban tidak dilakukan berarti perkaranya selesai". Apabila hal itu terjadi, akan menimbulkan ketidakpastian hukum yang mencederai rasa keadilan masyarakat, sehingga hakim pengadilan negeri harus menyatakan bahwa tuntutan jaksa untuk menghentikan prosesnya karena kewajiban mediasi tidak dilakukan, "tidak diterima" dan hakim tetap mengadili sesuai dengan keyakinannya. Dalam hal hakim pengadilan negeri mengabulkan tindakan jaksa, maka pengadilan yang 
lebih tinggi (Pengadilan Tinggi atau Mahkamah Agung) harus menyatakan bahwa putusan hakim pengadilan negeri "batal demi hukum."

Hakim Pemeriksa Perkara dalam pertimbangan putusan wajib menyebutkan bahwa perkara telah diupayakan perdamaian melalui Mediasi dengan menyebutkan nama Mediator. Hakim Pemeriksa Perkara yang tidak memerintahkan Para Pihak untuk menempuh Mediasi sehingga Para Pihak tidak melakukan Mediasi telah melanggar ketentuan peraturan perundang-undangan yang mengatur mengenai Mediasi di Pengadilan. Dalam hal terjadi pelanggaran apabila diajukan upaya hukum, maka Pengadilan Tingkat Banding atau Mahkamah Agung dengan putusan sela memerintahkan Pengadilan Tingkat Pertama untuk melakukan proses Mediasi. Ketua Pengadilan menunjuk Mediator Hakim yang bukan Hakim Pemeriksa Perkara yang memutus. Proses Mediasi sebagaimana dimaksud dilakukan paling lama 30 (tiga puluh) hari terhitung sejak diterimanya pemberitahuan putusan sela Pengadilan Tinggi atau Mahkamah Agung. Ketua Pengadilan menyampaikan laporan hasil Mediasi berikut berkas perkara ke Pengadilan Tinggi atau Mahkamah Agung. Berdasarkan laporan tersebut, Hakim Pemeriksa Perkara pada Pengadilan Tinggi atau Mahkamah Agung menjatuhkan putusan.

PERMA No.1 Tahun 2016 tidak menjelaskan "putusan hakim" akibat hukum apabila mediasi tidak dilakukan bagi perkara yang tidak dilakukan upaya hukum, tetapi Pasal 2 ayat (3) PERMA No.1 Tahun 2008 menjelaskan bahwa tidak ditempuhnya proses mediasi berdasarkan PERMA itu merupakan pelanggaran terhadap ketentuan pasal 130 HIR/154 Rbg yang menyatakan putusan batal demi hukum. Selanjutnya Pasal 2 ayat (4) PERMA No. 2 Tahun $2003^{43}$ menyatakan bahwa Hakim dalam pertimbangan putusan perkara wajib menyebutkan bahwa perkara yang bersangkutan telah diupayakan perdamaian melalui mediasi dengan menyebutkan nama mediator untuk perkara tersebut.

43 PERMA No. 2 Tahun 2003 jo PERMA No.1 Tahun 2008 diubah oleh PERMA No.1 Tahun 2016, namun PERMA No. 2 Tahun 2003 jo PERMA No.1 Tahun 2008 tetap dapat diberlakukan selama tidak bertentangan dengan atau PERMA No.1 Tahun 2016 tidak mengatur. 
Adapun proses mediasi ini dilakukan dengan ditengahi oleh pihak kepolisian sebagai mediator yang menengahi pertemuan korban dan pelaku untuk menyelesaikan kasusnya. ${ }^{44}$ Pelaksanaan mediasi ini dikenal dengan mediasi penal. Mediasi penal ditempuh apabila terjadi pelanggaran tindak pidana ringan dan kasus-kasus yang berkaitan dengan delik aduan seperti kasus pelanggaran dibidang KI. Mediasi ini dilakukan karena adanya kewenangan diskresi dari kepolisian dan diatur dalam surat edaran Kapolri No. Pol: B/3022/XXII/2009/SDEOPS tentang Penanganan Kasus Melalui Alternative Dispute Resolution yang menekankan penyelesaian kasus pidana dengan prosedur alternatif penyelesaian sengketa sepanjang disepakati oleh para pihak.

Dengan demikian, maka penyelesaian sengketa KI melalui mediasi penal telah menerapkan konsep keadilan restroaktif yakni menempatkan kembali korban dalam posisinya yang semula dibandingkan dengan menjatuhkan pidana kepada pelaku, sehingga bagi pemegang hak eksklusif yang telah dilanggar haknya akan mendapatkan ganti kerugian, ${ }^{45}$ atau pemulihan sebagaimana pendapat $\mathrm{G}$ Bazemore dan Mark Umbreit "Restorative Justice is about restoring victims, restoring offenders, and restoring comunicates." (keadilan adalah tentang pemulihan korban, memulihkan pelanggar, dan memulihkan komunikasi), ${ }^{46}$ dan Tony Marshall ${ }^{47}$ yang mengatakan "Restorative Justice is a process whereby all the parties with a stake in a particular offence come together to resolve collectively how to deal with the aftermath ot the offence and its implication for the future," (Restorative Justice adalah sebuah proses dimana para pihak yang berkepentingan dalam pelanggaran tertentu bertemu bersama untuk menyelesaikan persoalan

44 Diah Ratnasari Hariyanto, Konstruksi Mediasi Penal dalam Penyelesaian Tindak Pidana Ringan di Indonesia, Disertasi Universitas Udayana, Denpasar, hlm 10. Lihat juga Gatri Puspa Dewi dan Dewa Nyoman Rai Asmara Putra, Tinjauan Yuridis Terhadap Mediasi Sebagai Alternatif Penyelesaian Sengketa Kekayaan Intelektual, 2018, hlm 12.

45 Id.

46 G. Bazemore and Mark Umbreit, Balanced and Restorative Justice Project, Oxford University Press, New York 2002, hlm 11.

47 Tony Marshall, Restorative Justice on Trial in Britain, Oxford University Press, New York, 2002, hlm 11. 
secara bersama-sama bagaimana menyelesaikan akibat dari pelanggaran tersebut demi kepentingan masa depan). ${ }^{48}$

Pengenaan hukum pidana terkait pelanggaran Hak Cipta yang mengharuskan dilakukan mediasi terlebih dahulu selain pembajakan sesuai dengan fungsi hukum pidana sebagai "ultimum remedium' yaitu upaya terakhir apabila hukum lainnya tidak dapat memberikan penyelesaian. Sedangkan alasan untuk tindak pidana pembajakan tidak dilakukan mediasi (mediasi penal) ${ }^{49}$ tetapi langsung di proses melalui pengadilan negeri karena perbuatan tersebut pencerminan degradasi moral atau akhlak dan tidak adanya penghargaan kepada pihak lain yang bersusah payah untuk menghasilkan kreasi sehingga tidak sesuai dengan teori pelindungan KI (khususnya reward theory) dan kepentingan negara dirugikan serta pencederaan terhadap prinsip kemanusiaan yang adil dan beradab dan keadilan sosial bagi seluruh rakyat Indonesia (sila ke 2 dan ke 5 Pancasila).

\section{Penutup}

Berdasarkan penafsiran sistematis dan prinsip lex superior derogat legi inferiori, makna mediasi dalam Pasal 95 ayat (4) Undang-Undang Hak Cipta bukan penyelesaian sengketa secara litigasi tetapi merupakan sengketa di luar pengadilan (non litigasi) sebagaimana diatur dalam UU No 30 Tahun 1999, atau melalui Badan Arbitrase dan Mediasi Kekayaan Intelektual (BAM KI). Penyelesaian sengketa non litigasi tersebut termasuk plagiarisme yang penyelesaiannya dilakukan melalui hukum perdata tetapi tidak wajib mediasi. Namun, apabila plagiarisme tersebut ditempuh melalui mekanisme hukum pidana, maka wajib dilakukan mediasi (mediasi penal) dan termasuk mediasi

48 https://media.neliti.com/media/publications/183777-ID-penerapan-mediasi-dalampenyelesaian-sen.pdf. Diakses 15 Desember 2019.

49 Penggunaan mediasi penal di dalam Hak Cipta didasari penyelesaian tindak pidana mengedepankan ganti rugi yang sepadan dengan karya cipta dari pencipta. Selain itu memungkinkan pelaku untuk menyadari kesalahannya dan tidak mengulangi lagi tindakannya tanpa harus dikenai sanksi pidana. Lihat Dewa Gede Yudi Putra Wibawa, et al, Upaya Mediasi Dalam Penyelesaian Sengketa Pelanggaran Hak Cipta, e journal Ilmu Hukum Kerta Wicara, hlm 11, Fakultas Hukum Universitas Udayana. Diakses 12 Juni 2020. 
secara litigasi sebagaimana diatur dalam Peraturan Mahkamah Agung No. 1 Tahun 2016.

Akibat hukum tidak dilakukan Mediasi terlebih dahulu untuk tindak pidana selain pembajakan dalam Pasal 95 (4) Undang-undang Hak Cipta proses perkaranya tidak berhenti tetapi tetap berlanjut untuk menjamin kepastian hukum dan keadilan, sehinggga apabila jaksa menghentikan tuntutannya dengan alasan tidak ada ketentuannya, hakim Pengadilan Negeri harus menyatakan "tidak diterima". Namun dalam hal hakim mengabulkan tuntutan jaksa untuk menghentikan prosesnya, maka hakim pengadilan banding (Pengadilan Tinggi) dan atau kasasi (Mahkamah Agung) harus menyatakan bahwa putusan hakim Pengadilan Negeri batal demi hukum.

Ketentuan tentang keharusan mediasi untuk tindak pidana selain pembajakan sebagaimana tercantum dalam Pasal 95 ayat (4) UU Hak Cipta perlu ditindaklanjuti dengan Peraturan Pelaksanaan agar norma tersebut menjadi jelas dan menjamin kepastian hukum. Perlu sosialisasi BAM KI sebagai badan khusus untuk menyelesaikan pelanggaran KI, agar perkara KI tidak perlu diajukan melalui pengadilan niaga atau penyelesaian sengketa alternatif sebagaimana diatur dalam UU No. 30 Tahun 1999, sehingga penyelesaian sengketa lebih cepat, tidak memerlukan prosedural yang rumit, dan ditangani oleh pihak yang lebih berkompeten, serta tercapainya upaya penyelesaian sengketa cepat, mudah , biaya murah, akurat dan win-win solution.

Hakim pengadilan niaga atau pengadilan negeri perlu berhati hati menangani mediasi untuk pelanggatan hukum terhadap KI selain pembajakan misalnya penyelesaian kasus plagiarisme (melalui mekanisme hukum perdata atau hukum pidana). Perbedaan penanganan kasus tersebut memiliki akibat atau konsekuensi yuridis berkaitan dengan sifatnya (wajib atau tidak wajib mediasi) dan kewenangan absolut dari masing masing pengadilan tersebut (pengadilan niaga atau pengadilan negeri). 


\section{Daftar Pustaka}

\section{Buku:}

G. Bazemore, and Mark Umbreit, Balanced and Restorative Justice Project, Oxford University Press, New York 2002.

Ida Bagus Rahmadi Suprananca, Kerangka Hukum dan Kebijakan Investasi Langsung di Indonesia, cet. 1, Ghalia Indonesia, Bogor, 2006.

John Locke, The Second Treatise of Government, Barnes \& Noble Publishing, Inc. USA, 2004.

Joni Emirzon, Alternatif Penyelesaian Sengketa di Luar Pengadilan, Gramedia Pustaka Utama, Jakarta, 2001.

Khotibul Umam, Penyelesaian Sengketa di luar Pengadilan, Pustaka Yustisia, Yogyakarta, 2010.

O. Granstrand, The Economics and Management of Intellectual Property: Towards Intellectual Capitalism, Edward Elgar Publishing Limited, Cheltenham, UK, 1999. Henry Campbell Black, Black's Law Dictionary, West Publishing Co., St. Paul, 1989.

Munir Fuady, Pengantar Hukum Bisnis, Menata Bisnis Modern di Era Global, PT Citra Aditya Bakti, Bandung, 2002.

R. Soeroso, Pengantar Ilmu Hukum, Sinar Grafika, Jakarta, 2011.

Satjipto Rahardjo, Hukum Progresif Sebuah Sintesa Hukum Indonesia, Genta Publishing, Yogyakarta, 2009.

Sholih Mu'adi: Penyelesaian Sengketa Hak Atas Tanah Perkebunan Dengan cara Litigasi Dan Nonlitigasi, Prestasi Pustakarya, Jakarta, 2010.

Takdir Rahmadi, Mediasi: Penyelesaian Sengketa Melalui Pendekatan Mufakat, PT. Raja Grafindo Persada, Jakarta, 2010.

Tony Marshall, Restorative Justice on Trial in Britain. Oxford University Press, New York, 2002.

\section{Artikel, Penelitian dan Makalah:}

Aditya Pandu Wicaksono dan Dekar Urumsah, 2017, "Perilaku Cerita Dari Mahasiswa Yogyakarta", Jurnal Aplikasi Bisnis, Volume 17 Nomor 1 Bulan Juli.

Debora C. Surono, Penegakan Hukum Terhadap Pembajakan Karya Seni Musik Menurut Undang-Undang Nomor 28 Tahun 2014 Tentang Hak Cipta, Lex Privatum Vol. VI/No. 2/April/2018.

Derclaye, E. Intellectual Property Rights and Human Rights: Coinciding and Cooperating. Dalam Torremans, P. (Ed.). Intellectual Property and Human Rights. The Netherlands: Kluwer Law International, 2008.

Dewa Gede Yudi Putra Wibawa, et al, Upaya Mediasi Dalam Penyelesaian Sengketa Pelanggaran Hak Cipta, Jurnal Ilmu Hukum Kerta Wicara, Fakultas Hukum Universitas Udayana, 2019.

Dewi Tuti Muryati, and B. Rini Heryanti. "Pengaturan dan Mekanisme Penyelesaian Sengketa Nonlitigasi di Bidang Perdagangan." Jurnal Dinamika Sosbud 3, No. 1 (2011). 
Diah Ratnasari Hariyanto, Konstruksi Mediasi Penal dalam Penyelesain Tindak Pidana Ringan di Indonesia, Disertasi Universitas Udayana, Denpasar, 2018.

Ferol Mailangkay, Kajian Hukum Tentang Hak Moral Pencipta dan Pengguna Menurut Undang-Undang Nomor 28 Tahun 2014 Tentang Hak Cipta, Lex Privatum Vol. V/No. 4/Juni/2017.

Gatri Puspa Dewi dan Dewa Nyoman Rai Asmara Putra, Tinjauan Yuridis Terhadap Mediasi Sebagai Alternatif Penyelesaian Sengketa Kekayaan Intelektual, Makalah, tanpa tahun.

Hughes, J. The Philosophy of Intellectual Property. Georgetown Law Journal, 1988. No. 77 Vol 287, 1988.

Ivan Renaldi, Optimalisasi Alternatif Penyelesaian Sengketa Hak Kekayaan Intelektual Bidang Desain Industri (Studi Industri Mebel dan Kerajinan Kabupaten Jepara), Privat Law , Vol: 6 No: 12018.

Kamaruddin, Mediasi Dalam Pandangan Hukum Progresif Suatu Alternatif Penyelesaian Konflik Keluarga, Jurnal Al-'Adl, Vol. 11 No. 2, Juli 2018.

Marthen B. Salinding, "Dasar Filosofi Mediasi Sebagai Pilihan Penyelesaian Sengketa Lingkungan Hidup", garuda. risetdikti, (2017).

Riandhani Septian Chandrika, Raymond Edo Dewanta Magister Kenotariatan, Fakultas Hukum, Universitas Airlangga Pembajakan Produk Digital : Kajian Kritis Konsep Pembajakan di Bidang Hak Cipta Dalam Perspektif Hukum Positif dan Hukum Islam, RechtIdee, Vol. 14, No. 1, Juni 2019.

Ros Angesti Anas Kapindha, Salvatia Dwi M, and Winda Rizky Febrina, "Efektivitas dan Efisiensi Alternative Dispute Resolution (ADR) Sebagai Salah Satu Penyelesaian Sengketa Bisnis Di Indonesia", Privat Law, 12, No. 4 (2014).

Sudjana, Efektivitas dan Efisiensi Penyelesaian Sengketa Kekayaan Intelektual Melalui Arbitrase dan Mediasi Berdasarkan Undang-Undang Nomor 30 Tahun 1999, Ajudikasi : Jurnal Ilmu Hukum, Vol. 2 No. 1, Juni 2018.

Taufikkurrahman, Alternative Dispute Resolution (ADR) Dalam Penyelesaian Sengketa Konsumen, Iqtishadia, Jurnal Ekonomi Perbankan Syariah,Vol. 2 No. 1, 2015.

Yuniar Kurniawaty, Efektivitas Alternatif Penyelesaian Sengketa Dalam Sengketa Kekayaan Intelektual (Alternative Dispute Resolution On Intellectual Property Dispute), Jurnal Legislasi, Vol. 14 No. 02 - Juni 2017.

Zen Umar Purba, Peranan BAM HKI dalam Penyelesaian Permasalahan Lembaga Manajemen Kolektif, 2013.

\section{Dokumen digital:}

Doni Dermawan, "Implementasi Peraturan Mahkamah Agung RI Nomor 1 Tahun 2016 Tentang Prosedur Mediasi di Pengadilan". http://www.ptajambi.go.id/11-artikel/3870-implementasi-peraturan-mahkamah-agungri-nomor-1-tahun-2016-tentang-prosedur-mediasi-di-pengadilan. Diakses 5 Desember 2019.

Basuki Antariksa, "Landasan Filosofis dan Sejarah Perkembangan Perlindungan Hak Kekayaan Intelektual: Relevansinya Bagi Kepentingan Pembangunan Di Indonesia". https://www.kemenpar. go.idasset_admin/ assets/ uploads/ 
media/ old_all/Art_19-Landasan\%20Filosofis\%20HKI.pdf. Diakses Desember 2019.

Jeremy Bentham, "An Introduction to the Principles of Morals and Legislation". London: 1. http://books.google. co.id/ Diakses 24 Desember 2019.

Idris Talib, "Bentuk Putusan Penyelesaian Sengketa Berdasarkan Mediasi", tersedia dalam file:///C:/Users/user/AppData/Local/Temp/1295- 24821-SM.pdf. Diakses 9 Desember 2019.

https://media.neliti.com/media/publications/183777-ID-penerapan-mediasidalam-penyelesaian-sen.pdf. Diakses 15 Desember 2019.

http://www.patenindonesia.com/ Diakses 17 Desember 2019.

https://www.hukumonline.com/berita/baca/lt5118dd47bc07e/arbitrase-danmediasi-hki-belum-dilirik/ Diakses 20 Desember 2019.

https://www.kajianpustaka.com/2018/10/pengertian-jenis-penyebab-danpenyelesaian-sengketa. html. Diakses 27 Desember 2019.

http://ilib.usm.ac.id/ sipp/doc/jurnas/gdl-usm-- dewitutimu-87-1-pengature.pdf. Diakses 5 Januari 2020.

http://www.pta-jambi.go.id/11-artikel/3870-implementasi-peraturan-

mahkamah-agung-ri-nomor-1-tahun-2016-tentang-prosedur-mediasi-dipengadilan. Diakses 7 Januari 2020.

https://www.cnnindonesia.com/teknologi/20191231141341-185-

461331/pelanggaran-merek-paling-banyak-diadukan-ke-kemenkumham.

Diakses 10 Juni 2020.

http://ilib.usm.ac.id/sipp/doc/jurnas/gdl-usm--dewitutimu-87-1-pengatur-e.pdf.

Diakses 17 Januari 2020.

Nahrowi, "Plagiat dan pembajakan Karya Cipta dalam Hak Kekayaan Intelektual", Salam : Jurnal Filsafat dan Budaya hukum, 227-238, http://repository. uinjkt.ac.id/dspace/bitstream/ 123456789/ 31355/1/ Nahrowi.pdf. Diakses 15 Januari 2020.

www.putusan.mahkamahagung.go.id. Diakses 13 Juni 2020.

\section{Perundang-undangan:}

Undang-Undang R.I No. 30 Tahun 1999, Arbitrase dan Penyelesaian Sengketa Alternatif, L.N.R.I 1999 No.138.

Undang-Undang R.I No. 49, 2009 tentang Kekuasaan kehakiman, L.N.R.I No. 158.

Undang-Undang R.I No. 28 Tahun 2014. Hak Cipta, L.N.R.I No. 266.

Herziene Inlandsch Reglemen (HIR), Stbl 1941 No. 44.

Rechtsreglement voor de Buitengewesten (RBg), Stbl 1927 No. 227.

Peraturan Mahkamah Agung R.I No. 2 Tahun 2003, Prosedur Mediasi Di Pengadilan, 11 September 2003.

Peraturan Mahkamah Agung R.I No. 1 Tahun 2008, Prosedur Mediasi Di Pengadilan, 31 Juli 2008.

Peraturan Mahkamah Agung R.I No. 1 Tahun 2016, B.N.R.I 2016 No.175, tanggal 4 Februari 2016. 